\title{
Analysis of University Students' Views about the Quality of Faculty Life Using Various Variables
}

\author{
Ömay ÇOKLUK BÖKEOĞLU* Kürşad YILMAZ*
}

\begin{abstract}
The aim of this study is to determine if views of university students about the quality of faculty life differ depending on variables such as gender, age, grade, preference, being a member of a certain student community or not. In this study "Scale of Quality of Faculty Life" was used. 690 students from different faculties of Ankara University were included in the study. When we examined differences between faculties, the study showed that significant differences were not in the dimension of "Class Atmosphere and Satisfaction with Relations to Students", but in those of "Satisfaction with Instructors", "Satisfaction with Faculty" and in the "Total" score. It was determined that there were no significant differences in the dimension of "Satisfaction with Instructors" depending on gender, whereas significant differences were in "Class Atmosphere and Satisfaction with Relations to Students", and "Satisfaction with Faculty" and in the total score.
\end{abstract}

Keywords: Quality, Faculty Life, University Students

\footnotetext{
${ }^{*}$ Ass. Prof. Dr. Ankara University Faculty of Educational Sciences

** PhD. Dumlupınar University Faculty of Education
} 


\section{SUMMARY}

Quality is something important in adults' lives (Schmidt ve Lunenberg, 1989). When we mention quality of life our society generally tend to take general individual happiness into account. Happiness depends on personal decisions of individuals and strangers (Kourelahti, 1998). Similarly, quality of school life is obviously important in students' lives (Leonard, Bourke and Schofield, 2001; Leonard, Bourke and Schofield, 2002; Leonard, Bourke and Schofield, 2003b). However, students' expectations from schools or satisfaction levels have so far been studied rarely and researchers only have an unclear definition of this concept. The related model designed by Gerson (1976), Burt, Wiley, Minnor and Murray (1978), researchers on quality, has further been developed and transferred to schools (Kourelahti, 1999). The concept of "Quality of School Life" from environmental studies by adults (The U.S. Association of Environmental Protection, 1973) was adapted to primary, secondary schools and high schools by Epstein and Mc Portland (Epstein and McPartland, 1976).

Quality of school life can be defined as a synthesis of good and bad experiences at school and other feelings and private situations in school life and related results. Other feelings in school life and related results may be the main signals of quality level of school life for teachers and students (Leonard, 2002; Schofield and Bourke, 1997; Waugh and Hyde, 1993).

Epstein and McPartland (1976) believed attitude towards school should be handled as an individual educational output, differentiating its relation to academic achievement. They suggested that structure was influenced by formal and informal expectations of school, social experiences and experiences about post at school, figures of authority and relations to colleagues. In their study, Epstein and McPartland (1976) used the term of quality of school life and thought that three factors contributed to quality of school life. These factors are "satisfaction with school", "commitment to class tasks" and "reactions to teachers". In the present study, we attempted to conduct previous studies on quality of school life at primary, secondary schools and high schools in faculties. To this end, the content of quality of faculty life was structured with regards to literature on quality of school life and features of school life at university.

Faculties, as educational institutions, should be places where students are not only taught at graduate level but also attend eagerly, participate in social, cultural and sports activities and improve their way of thinking.

Quality of faculty life was formed regarding dimensions in studies of quality of school life. Subdimensions of "Satisfaction with School", 
"Commitment to Class Tasks" and "Reactions to Teacher" in such studies were named as "Satisfaction with Class Atmosphere and Relations to Students", "Satisfaction with Instructors" and "Satisfaction with Faculty" in our study.

We can say that the general aim of studies on quality of faculty life is "to provide educational settings where students may state their views on educational and instructional activities and both instructors and students attend eagerly". In the present study, in the light of the information above, we attempted to determine views of university students about quality of faculty life. To this end, we asked for their views and tried to get the answers of the following questions.

We examined if the scores in subscales of quality of faculty life and the total score differ significantly depending on students' 1) Faculties, 2) Gender 3) Age 4) Being a member of a certain student community at faculty or not 5) Preference to spend time at faculty after class or not 6) Grade 7) Number of preference of their department in the university entrance sheet 8) Answers to this question "If you had a chance, would you prefer the same faculty again?"

In this study of scan model "Scale of Quality of Faculty Life" was used. This scale has three sub dimensions like "Satisfaction with Class Atmosphere and Relations to Students (7 items)", "Satisfaction with Instructors (15 items)" and "Satisfaction with Faculty (15 items)". The study group included 690 students from Faculty of Educational Sciences, Faculty of Science, Faculty of Theology, Faculty of Agriculture and School of Physical Training and Sports of Ankara University. In the current study, a t test was used for the comparison of subscale scores in the Scale of Quality of Faculty Life and the total score depending on gender regarding the answers to the following questions; "If you had a chance, would you prefer the same faculty again?", "Are you a member of a certain student community at your faculty?" and "Do you prefer spending time at your faculty after class?", whereas one way ANOVA was used for comparison depending on faculties, grade, class, age and number of preference. In order to determine the source of difference for significant $F$ values, Scheffe Test, a multiple comparative test, was used.

When we examine the results from the comparative study of answers to the questions in the Scale of Quality of Faculty Life depending on their faculties, there is no significant difference between faculties in the dimension of "Satisfaction with Class Atmosphere and Relations to Students", whereas the differences in the other two dimensions and the total 
score are significant. Faculty of Science has the highest average in the dimension of "Satisfaction with Instructors", while students of Faculty of Theology has the lowest. Faculty of Educational Sciences has the highest average in the dimension of "Satisfaction with Faculty", while students of Faculty of Theology has the lowest. For the total scores we have a similar result like students from Faculty of Science has the highest average, while students of Faculty of Theology have the lowest. In this case, we can say that students at Faculty of Science generally have positive perceptions and assessments about their faculties, whereas those of the students at Faculty of Theology are relatively negative.

Comparative studies depending on gender showed that the average of girls was higher than that of the boys, which meant girls and boys assessed the current conditions differently and perceptions and assessments of girls were more positive than the boys'. In fact, the main reason of that difference may be criteria and expectations of students while assessing conditions. Even in the situations where ideal conditions of any kind are provided, we can say that satisfaction and expectation levels of individuals are limited with realistic restrictions.

When we examine the comparative study depending on students' age, we see that there are significant differences in the dimension of "Satisfaction with Class Atmosphere and Relations to Students" and in the total score. It was determined that the younger the student, the higher the average was in general. Moreover, in the comparative study depending on students' class level it was shown that students at lower grades assessed their quality of faculty life more positively in general and that the higher the grade the more negative the satisfaction levels were. The reason may be different environments for students as grade becomes higher and students get older, and interests in things rather than the faculty itself as they get to know the environment and adapt themselves to it. Another reason may be they start to see certain things or qualities that they have got used to ordinary.

When we examine the results from the comparative study of the scores of the subscales and the answers to the question "Are you a member of a certain student community at your faculty?", we see that the students who are not members of student communities had higher scores in each dimension and the total score regardless of significant differences and it is in fact not the result we expected. It may be viewed as students who are not very satisfied with their faculties tend to participate activities in order to essential their dissatisfaction. 
When we examine the comparative study depending on the answers to the question "Do you prefer to spend time at your faculty after class?", it was seen that differences between students who answered "yes" or "no" were not significant in any of the subdimensions and in the total score. Also, such a preference does not seem to be a crucial variable influencing perceptions and assessment on quality of faculty life.

When we examine the comparative study depending on the number of preference in the university entrance sheet concerning their department, it is observed that in general students whose departments were stated between the 6th and the 10th options had the highest average, whereas students whose departments were stated between the 1st and the 5th options had the lowest. This finding may show that students whose departments were stated between the 1st and the 5th options had higher expectations (probably not very realistic); therefore their perceptions and assessment are more negative.

When we examine the comparative study depending on the answers to the question "If you had a chance, would you prefer the same faculty again?" It was seen that differences between students who answered "yes" or "no" were not significant in any of the subdimensions and in the total score. Factors that influence students in their answer to that question may be related to different dimensions of faculty life that are not being examined, as well as to other personal, environmental or social variables. 


\title{
Üniversite Öğrencilerinin Fakülte Yaşamının Niteliğine İlişkin Görüşlerinin Çeşitli Değişkenler Açısından İncelenmesi
}

\author{
Ömay ÇOKLUK BÖKEOĞLU* \\ Kürşad YILMAZ ${ }^{* *}$
}

ÖZ. Bu çalışmanın amacı, üniversite öğrencilerinin fakülte yaşamının niteliğine ilişkin görüşlerinin cinsiyet, yaş, sınıf, tercih, herhangi bir öğrenci topluluğuna üye olup olmama gibi değişkenlere göre farklılık gösterip göstermediğini belirlemektir. Araştırmada, "Fakülte Yaşamının Niteliği Ölçeğì" kullanılmıştır. Araştırma Ankara Üniversitesi'nin farklı fakültelerinde öğrenim gören 690 öğrenci ile gerçekleştirilmiştir. Araştırmada fakültelere göre farklar incelendiğinde, "Sınıf Ortamı ve Öğrenci İlişkilerinden Memnuniyet" boyutunda anlamlı bir farklılığın olmadığı, ancak "Öğretim Elemanlarından Memnuniyet", "Fakülteden Memnuniyet" ve toplam puandaki farkların anlamlı olduğu görülmüştür. Cinsiyete göre "Öğretim Elemanlarından Memnuniyet" boyutunda anlamlı bir farklılığın olmadığı, buna karşılık "Sınıf Ortamı ve Öğrenci İlişkilerinden Memnuniyet", "Fakülteden Memnuniyet" ve toplam puana ilişkin farklılıkların anlamlı olduğu bulunmuştur. 18-19, 20-21, $22-23$ ve 24 ve üstü yaş gruplarına göre yapılan karşılaştırmada, "Sınıf Ortamı ve Öğrenci İlişkilerinden Memnuniyet" boyutu ve toplam puanda farkların anlamlı olduğu saptanmıştır.

Anahtar Kelimeler: Nitelik, Fakülte Yaşamı, Üniversite Öğrencileri

\footnotetext{
Yrd. Doç. Dr. Ankara Üniversitesi Eğitim Bilimleri Fakültesi, cokluk@education.ankara.edu.tr

** Dr. Dumlupınar Üniversitesi Eğitim Fakültesi, kursadyilmaz@gmail.com
} 


\section{GİRiș}

Günümüzde eğitimin niteliği ile ilgili bilgilerin elde edilmesinde, insani ve kültürel unsurların da incelenmesi önemli bir gereklilik olarak görünmektedir (Wilson, 1980). Pozitivist etki ile bağlantılı olarak ortaya çıkan durumlardan birisi de eğitim ya da eğitim yönetimi ile ilgili çalışmalarda, genellikle yönetici ve öğreticilerin fikirlerine başvurulmuş olması, öğrencilerin sadece öğrenip öğrenmedikleri ya da başarılarında bir gelişme olup olmadığı sorgulanan denekler gibi kullanılmış olmasıdır. Ancak, okul örgütü içindeki en önemli unsurlardan birisi olan öğrencilerin de okul örgütü içindeki görüşlerine mutlaka önem verilmelidir. Çünkü öğrencilerin yaşamının büyük bir kısmı okulda geçmektedir. Okulların varlığının ilk sebebi öğretmen ve yöneticiler değil, öğrenciler ve toplumdur (Şişman ve Turan, 2001). Bu bağlamda öğrencilerin okul ya da fakültedeki yaşamlarının niteliği de önem kazanmaktadır.

Nitelik, yetişkinlerin yaşamında önemli bir yere sahiptir. Yaşam niteliği denildiğinde genellikle toplumda; "genel bireysel mutluluk" anlaşılmaktadır. Mutluluk, insanların ve yabancıların bireysel kararlarına dayanmaktadır (Kourelahti, 1998). Yetişkinlerin yaşamında yaşam niteliği ne kadar önemli ise, öğrencilerin yaşamında da okul yaşamının niteliğinin çok önemli olduğu açıktır (Leonard, Bourke ve Schofield, 2001; Leonard, Bourke ve Schofield, 2002; Leonard, Bourke ve Schofield, 2003b). Ancak öğrencilerin okuldan beklentilerini ya da tatmin düzeylerini ifade edebildikleri durumlar çok nadir olarak çalışılmış ve bu çalışmalarda genellikle bu kavramın belli belirsiz tanımlanması ile yetinilmiştir. Alanyazında okul yaşamının niteliği ile ilgili çalışmalar (Epstein ve McPartland, 1976; Schmidt ve Lunenberg, 1989; Schmidt, 1992; Waugh ve Hyde, 1993; Mok ve McDonald, 1994; Ainley, 1999; Mok ve Flynn, 1997; Schofield ve Bourke, 1997; 2002; Leonard, 2002; Karatzias, Power ve Swanson, 2001) olsa da, fakülte yaşamının niteliği ile ilgili çalışmalar görece daha azdır.

Nitelik konusu ile ilgili çalışmalar yapan Gerson (1976), Burt, Wiley, Minnor ve Murray'nin (1978) bu konuyla ilgili olarak tasarlamış olduğu model (Akt. Kourelahti, 1998) geliştirilerek okula transfer edilmiştir. "Okul Yaşamının Niteliği”" kavramı yetişkinlerin çevre çalışmalarından (Birleşik Devletler Çevre Koruma Vakfi, 1973) ilkokul, ortaokul ve liselere Epstein ve McPortland (1976) tarafından uyarlanmıştır (Akt: Epstein ve McPartland, 1976) .

Okul yaşamının niteliği, okulla ilgili olumlu ve olumsuz deneyimlerin ve okul yaşamındaki ve sonuçlarındaki diğer duygular ile ilgili özel durumların bir sentezi olarak tanımlanabilir. Okul yaşamındaki ve 
sonuçlarındaki diğer duygular, öğretmen ve öğrenciler için okul yaşamının niteliği düzeyinin başlıca göstergeleri olabilir (Leonard, 2002; Schofield ve Bourke, 1997; Waugh ve Hyde, 1993).

Epstein ve McPortland (1976), okula karşı tutumun, akademik başarıyla ilişkisini ayırarak "farklı bir eğitim çıktısı" olarak ele alınması gerektiğine inanmışlar ve yaptıkları çalışmada okul yaşamının niteliği kavramını kullanmışlardır. Okul yaşamının niteliğine üç unsurun katkı yaptığına inanan araştırmacılar, bu faktörleri, "okuldan memnuniyet", "sınıf içi görevlere bağl1l1k" ve "öğretmenlere olan tepkiler" olarak ifade etmişlerdir.

Okuldan Memnuniyet, öğrencilerin okula karşı tepkilerini içermektedir. Çünkü okul gençlerin ve öğrencilerin yaşamlarının ana unsurudur. Okuldaki etkinliklere katılmada gönüllü olan ya da bu etkinliklere katılmaktan zevk alan öğrencilerin genel olarak akademik etkinliklerde de başarılı oldukları düşünülmektedir. Ayrıca okul yaşamı ile ilgili pozitif görüşlere sahip olan öğrencilerin, diğer öğrencilere okul ortamında yardım etme konusunda da daha başarılı oldukları düşünülmektedir (Schmidt, 1992; Schmidt ve Lunenberg, 1989).

Sinıf İçi Görevlere Bağlllık, öğrencilerin sınıf içi görevlere ilgi düzeylerini konu edinmektedir. Görev ve ödevler, okul ortamını diğer ortamlardan ayıran etkinliklerdir. Kısaca bu görevler, okulu okul yapan unsurlardır ve okul için yapılmaktadır. Okul ödevlerini ve projelerini ilginç ve önemli bulan öğrenciler, kavramları daha iyi şekilde öğrenebilmekte ve öğrenmeye karşı pozitif tutumlar geliştirmektedir (Schmidt, 1992; Schmidt ve Lunenberg, 1989).

Öğretmenlere Olan Tepkiler, öğrencilerin öğretmenlerle olan etkileşimlerini ve eğitime dayalı öğrenci değerlendirmesini konu edinmektedir. Öğrenci-öğretmen ilişkileri; eğitim hedeflerinin öğrenciler tarafından kabul edilmesi (sürece katma), okul uygulamalarını öğrencilerin algılaması, öğrencilerin bağımlı ve bağımsız davranışları ve okul içi ve dışı otoritelere karşı tutumları gibi konularda önemli bir unsurdur (Schmidt, 1992; Schmidt ve Lunenberg, 1989).

Okul yaşamının niteliğine yönetici ve öğretmenler tarafından özel bir önem verilmektedir. Çünkü okul yaşamının niteliği ile öğrencilerin akademik başarıları arasında ilişki bulunmaktadır ve bu nedenle de daha fazla önem kazanmaktadır. Ayrıca öğrencilerin yaşamının önemli bir kısmı okulda geçmektedir (Bourke ve Smith, 1989). Öğrencilerin öğretmenlere olan tepkileri ve okuldaki görevlere bağl1lıkları, okulun etkililiğinde önemli roller oynamaktadır (Schmidt ve Lunenberg, 1989). 
Okul yaşamının niteliği ile ilgili çalışmalar, okulun etkililiği ve gelişiminin ölçülmesi gibi amaçlarla yapılmaktadır. Ayrıca başka bir amaç da, öğrencilerin yüksek yaşam niteliğine sahip olmalarının sağlanması, kapsamlı eğitim uygulamalarının ve öğretmenlerin öğretim etkinliklerinin geliştirilmesidir (Leonard, Bourke ve Schofield, 2003b). Öğrencilerin okul yaşamının niteliğini etkileyen memnuniyet ve stres gibi olumlu ve olumsuz durumların doğasının belirlenmesi ve buna yönelik ilginin arttırılması, hem öğrenciler, hem de eğitimciler için faydalıdır (Leonard, Bourke ve Schofield, 2001; Leonard, Bourke ve Schofield, 2002; Leonard, Bourke ve Schofield, 2003a). Yapılan araştırmalar göstermektedir ki, okula devam ve okulda olumlu deneyim oranı yüksek olan ögrenciler, okula karşı daha olumlu tutumlar geliştirmektedir (Schofield ve Bourke, 1997).

$\mathrm{Bu}$ çalışmada, daha önce ilköğretim ve ortaöğretim seviyelerinde yapılmış olan okul yaşamının niteliği çalışmaları fakülte düzeyine taşınmaya ve bu düzeyde gerçekleştirilmeye çalışılmıştır. Bu amaçla okul yaşamının niteliği ile ilgili alanyazın taranmış ve yükseköğretim seviyesinde okul yaşamının özellikleri düşünülerek çalışmanın içeriği oluşturulmuştur.

Tüm eğitim düzeyleri için geçerli olmakla birlikte, özellikle yükseköğretim düzeyinde eğitim veren fakültelerin, sadece eğitim ve öğretim yapılan kurumlar değil, aynı zamanda öğrencilerin isteyerek gelecekleri, sosyal, kültürel ve sportif etkinliklere katılabilecekleri, düşünce sistemlerini geliştirebilecekleri yerler olmalıdır.

Fakülte yaşamının niteliği, okul yaşamının niteliği çalışmalarında yer alan boyutlar da göz önüne alınarak oluşturulmuştur. Okul yaşamının niteliği çalışmalarında yer alan "Okuldan Memnuniyet", "Sınıf İçi Görevlere Bağl1lık" ve "Öğretmenlere Olan Tepkiler" alt boyutları, bu çalışmada "Sınıf Ortamı ve Öğrenci İlişkilerinden Memnuniyet", "Öğretim Elemanlarından Memnuniyet" ve "Fakülteden Memnuniyet" alt boyutları olarak şekillendirilmiştir.

Sınıf Ortamı ve Öğrenci Illişkilerinden Memnuniyet. $\mathrm{Bu}$ boyut, öğrencilerin öğretim ile ilişkili etkinliklere karşı duydukları ilgiyi kapsamaktadır. Eğitim kurumlarında yapılan etkinlikler, bu kurumları diğer kurumlardan ayıran özellikler olması açısından önemli görülmektedir. Kısaca fakültede yapılan etkinliklere ilgi duyan öğrenciler, gerçekleri ve kavramları daha net bir şekilde öğrenebilmekte ve öğrenmeye karşı pozitif tutumlar geliştirebilmektedir. Bu boyutta, öğrenciler arası ilişki, arkadaşlık, yardımlaşma, dersliklerin durumu ve dersler için uygunluğu gibi görüşler yer almaktadır.

Öğretim Elemanlarından Memnuniyet. Bu boyut öğrencilerin öğretim elemanları ile olan etkileşimlerini ve eğitime dayalı öğrenci değerlendirmelerini içermektedir. Öğrenci-öğretim elemanı ilişkileri; eğitim 
hedeflerinin öğrenciler tarafindan kabul edilmesi, okul uygulamalarının öğrencilerce algılanması gibi konularda önemli bir unsurdur. Bu boyut, öğretim elemanlarının öğrencilerle ilişkileri, öğrencilerle ilgilenmeleri, derslerdeki durumları, öğrencilerin gelişimi için çalışmaları, öğrencileri yönlendirmeleri, farklı öğretim yöntem ve teknikleri ile sınıf ortamında teknoloji kullanımı ve eğitim-öğretim etkinliklerindeki durumları ile ilgili görüşleri içermektedir.

Fakülteden Memnuniyet. Bu boyut öğrencilerin fakülteye karşı tepkilerini incelemektedir. Çünkü üniversite öğrencilerinin günlük yaşamının önemli bir kısmı fakültede geçmektedir. Bu boyut, öğrencilerin fakültenin bir üyesi, bir parçası olmaktan memnun olmaları, her türlü uygulamanın eşit ve adil bir şekilde uygulanması, düzenlenen sosyal, kültürel, sportif etkinliklerin durumu, öğrenciler arasındaki ilişkiler, etkinliklere katılım, araç-gereçlerin ve kaynakların özenli kullanımı ile fiziki mekânların durumuyla ilgili görüşlerden oluşmaktadır.

Artık öğrencilerin fakülte yaşamının niteliği ile ilgili görüşlerine çok önem verilmektedir. Öyle ki Batı' da birçok üniversite, düzenli olarak fakülte yaşamının niteliği araştırmaları yapmakta ve bu araştırmaların sonuçlarına göre politika ve eylem planları geliştirmekte, niteliğin arttırılması için birçok etkinlik düzenlenmektedir. Yapılan çalışmalar bazı üniversitelerde fakültelerin geliştirilmesi ile ilgili çalışmaların bir parçası olarak yürütülmektedir. Fakülte yaşamının niteliği ile ilgili olarak yapılmış olan bir çalışmada (www.cnu.edu), bu konudaki çalışmaların aşağıda yer alan noktalarda önemli olduğu vurgulanmaktadır:

1. Gelecek ile ilgili politika ve eylem planlarının belirlenmesinde,

2. Öğrencilerin yönetime katılımının arttırılmasında,

3. Öğrencilerin sorunlarının çözümünün kolaylaştırılmasında,

4. Öğrenciler ile fakülte yönetimi arasındaki iletişim ve işbirliğinin geliştirilmesinde,

5. Öğrencilerin sosyo-kültürel etkinliklere katılımının arttırılmasında,

6. Eğitim ve öğretim etkinliklerinin geliştirilmesinde,

7. Eğitim ve öğretim etkinliklerinin geliştirilmesi için öğrenci görüşlerine yer verilmesinde,

8. Öğrencilerin araştırma yeterliklerinin geliştirilmesinde,

9. Öğrencilerin liderlik becerilerinin geliştirilmesinde,

10. Akademik mekânların yerleşim ve tasarımında öğrenci görüşlerine yer verilmesinde, 
11. Öğrencilerin isteyerek gelecekleri eğitim ortamlarının oluşturulmasında,

12. Kütüphane, kantin ve benzeri alanların öğrenci görüşlerine göre geliştirilmesinde,

13. Öğretim elemanları ve diğer fakülte çalışanları ile öğrenciler arasındaki ilişkilerin geliştirilmesinde,

14. Eğitim hedeflerinin başarıyla gerçekleştirilmesinde.

Yukarıdaki ifadelerden anlaşıldığı gibi, bu tür çalışmaların genel amacının "eğitim öğretim etkinliklerinin geliştirilmesinde ögrrencilerin fikirlerinin alınması ve ögrencilerin isteyerek gelecekleri eğitim ortamlarının oluşturulması" olduğu söylenebilir.

$\mathrm{Bu}$ çalışma, yukarıda tartışılan bilgi ve gelişmeler 1şığında, üniversite öğrencilerinin fakülte yaşamının niteliğine ilişkin görüşlerinin çeşitli değişkenler açısından incelenmesini amaçlamıştır. $\mathrm{Bu}$ amacı gerçekleştirmek için aşağıdaki sorulara yanıt aranmıştır:

Öğrencilerin Fakülte Yaşamının Niteliği Ölçeği alt ölçek puanları ve toplam puanı:

1. Fakültelerine,

2. Cinsiyetlerine,

3. Yaşlarına,

4. Öğrenim gördükleri sınıflara,

5. Fakültede herhangi bir öğrenci topluluğuna üye olup olmama durumlarına,

6. Ders dışı zamanlarını fakültede geçirmeyi tercih edip etmeme durumlarına,

7. Öğrenim gördükleri bölümü tercih sıralarına,

8. Tekrar tercih etme şansları olsa, aynı fakülteyi tercih etmeyi isteyip istememe durumlarına göre anlamlı farklılıklar göstermekte midir?

\section{YÖNTEM}

Bu bölümde, araştırmanın modeli, çalışma grubu, veri toplama aracı ve verilerin analizi başlıklarına yer verilmiştir.

\section{Araștırmanın Modeli}

Üniversite öğrencilerinin fakülte yaşamının niteliğine ilişkin görüşlerinin çeşitli değişkenler açısından incelenmesini amaçlayan bu 
araştırma tarama modelindedir. Tarama modeli, geçmişte ya da halen varolan durumları varolduğu şekilde betimlemeyi amaçlayan araştırma yaklaşımıdır (Karasar, 1995: 77). Araştırmada üniversite öğrencilerinin fakülte yaşamının niteliği hakkındaki görüşlerine başvurulmuştur.

\section{Çalışma Grubu}

Araştırmanın çalışma grubu; Ankara Üniversitesi Eğitim Bilimleri Fakültesi, Fen Fakültesi, İlahiyat Fakültesi, Ziraat Fakültesi ve Beden Eğitimi ve Spor Yüksek Okulu'nda öğrenim gören toplam 690 öğrenciden oluşmaktadır. Fakültelerin seçiminde sosyal bilimler ve fen bilimleri ayırımı dikkate alınmıştır. Her iki alandan da seçkisiz olarak iki fakülte seçilmiştir. Ayrıca çalışmada, yapıları fakültelerden farklı olan bir de yüksek okulun yer almasının uygun olacağı düşünüldüğünden, yine Ankara Üniversitesi'ne bağlı yüksek okullar içerisinden seçkisiz olarak belirlenen Beden Eğitimi ve Spor Yüksek Okulu çalışmaya dâhil edilmiştir. Tablo 1'de çalışma grubunun fakülte, sınıf ve cinsiyetlerine ilişkin dağılımlar yer almaktadır.

Tablo 1'de görüldüğü gibi, araştırmaya katılan üniversite öğrencilerinin \%35.50'si Eğitim Bilimleri Fakültesi, \%15.60'1 Fen Fakültesi, \%18.00'1 İlahiyat Fakültesi, \%17.40'1 Ziraat Fakültesi, \%13.20'si ise Beden Eğitimi ve Spor Yüksek Okulu öğrencisidir. Araştırmaya birinci sınıf öğrencileri dâhil edilmemiştir. $\mathrm{Bu}$ grupların henüz fakültelerini yeterince tanımadıkları ve gerçekçi olarak değerlendirme yapamayacakları düşünülerek görüşlerine başvurulmamıştır. Araştırmaya katılan öğrencilerin 210’u (\%30.40) ikinci sinıfta, 335'i (\%48.60) üçüncü sınıfta, 145'i (\%21.00) ise dördüncü sınıfta öğrenim görmektedir. Öğrencilerin 326's1 (\%47.20) kı, 364'ü (\%52.80) ise erkektir. Öğrencilerin yaş gruplarına göre dağılımları incelendiğinde ise, 97'sinin (\%14.10) 18-19 yaş, 313'ünün (\% 45.40) 20-21 yaş, 194'ünün (\%28.10) 22-23 yaş, 86'sının (\%12.50) 24 yaş ve üzerinde oldukları belirlenmiştir. 
Tablo 1. Çalışma grubundaki öğrencilere ait kişisel bilgiler

\begin{tabular}{|c|c|c|c|}
\hline Değişken & Düzey & $\mathbf{n}$ & $\%$ \\
\hline \multirow{6}{*}{ Fakülte } & Eğitim Bilimleri Fakültesi & 245 & 35.5 \\
\hline & Fen Fakültesi & 110 & 15.6 \\
\hline & İlahiyat Fakültesi & 124 & 18.0 \\
\hline & Ziraat Fakültesi & 120 & 17.4 \\
\hline & $\begin{array}{l}\text { Beden Eğitimi ve Spor Meslek Yüksek } \\
\text { Okulu }\end{array}$ & 91 & 13.2 \\
\hline & TOPLAM & 690 & 100 \\
\hline \multirow{4}{*}{ Sinif } & 2. Sinif & 210 & 30.4 \\
\hline & 3. Sinif & 335 & 48.6 \\
\hline & 4. Sinif & 145 & 21.0 \\
\hline & TOPLAM & 690 & 100 \\
\hline \multirow{3}{*}{ Cinsiyet } & Kadın & 326 & 47.2 \\
\hline & Erkek & 364 & 52.8 \\
\hline & TOPLAM & 690 & 100 \\
\hline \multirow{5}{*}{ Yaş } & $18-19$ & 97 & 14.1 \\
\hline & $20-21$ & 313 & 45.4 \\
\hline & $22-23$ & 194 & 28.1 \\
\hline & 24 ve yukarısı & 86 & 12.5 \\
\hline & TOPLAM & 690 & 100.0 \\
\hline
\end{tabular}

\section{Veri Toplama Aracı}

Araştırmanın verilerinin toplanmasında, Çokluk-Bökeoğlu ve Yılmaz (2006) tarafından geliştirilmiş olan "Fakülte Yaşamının Niteliği Ölçeği”" kullanılmıştır. Ölçek "Sınıf Ortamı ve Öğrenci İlişskilerinden Memnuniyet (7 madde)", "Öğretim Elemanlarından Memnuniyet (15 madde)" ve "Fakülteden Memnuniyet (15 madde)" olmak üzere üç alt boyuttan oluşmaktadır.

Sınıf Ortamı ve Öğrenci İlişkilerinden Memnuniyet boyutunda yer alan maddelerin faktör yük değerleri 0.39 ile 0.71 , madde-toplam korelasyonları ise 0.26 ile 0.45 arasında değişmektedir. Bu faktörün tek başına açıkladığ varyans \%34 ve faktöre ait Cronbach-Alpha içtutarlık katsayısı 0.67'dir.

Öğretim Elemanlarından Memnuniyet boyutunda yer alan maddelerin faktör yük değerleri 0.37 ile 0.67 , madde-toplam korelasyonları ise 0.32 ile 0.58 arasında değişmektedir. Bu faktörün tek başına açıkladığ varyans \%31, faktöre ait Cronbach-Alpha içtutarlık katsayısı ise 0.83'tür.

Fakülteden Memnuniyet alt boyutunda yer alan maddelerin faktör yük değerleri 0.32 ile 0.63 , madde-toplam korelasyonları ise 0.24 ile 0.49 arasında değişmektedir. Bu faktörün tek başına açıkladığ 1 varyans $\% 23$, faktöre ait Cronbach-Alpha içtutarlık katsayısı ise 0.75'tir. Fakülte 
Yaşamının Niteliği Ölçeği'nin tümüne ilişkin Cronbach-Alpha içtutarlık katsayısı da hesaplanmış ve 0.87 olarak bulunmuştur. Ölçek "katılıyorum", "kararsızım" ve "katılmıyorum" olmak üzere üçlü dereceleme şeklindedir. Ölçekteki bazı maddeler ters puanlanmaktadır. Ölçekten alınan yüksek puan fakülte yaşamının niteliği ile ilgili ifadelere ilişkin olumlu görüşü, düşük puan ise olumsuz görüşü göstermektedir.

\section{Verilerin Analizi}

Araştırmada Fakülte Yaşamının Niteliği Ölçeği alt ölçek puanları ve toplam puanın cinsiyete göre, "tekrar tercih şansınız olsa aynı fakülteyi tercih eder miydiniz?", "fakültenizde herhangi bir öğrenci topluluğuna üye misiniz?" ve "ders dışı zamanlarınızı fakültede geçirmeyi tercih ediyor musunuz?" sorularına göre karşılaştııılmasında ilişkisiz t testi; fakültelere, sınıfa, yaş ve tercih sıralarına göre karşılaştırılmasında ise tek yönlü varyans analizi (ANOVA) kullanılmıştır. Anlamlı çıkan F değerleri için farkın kaynağını belirlemek üzere çoklu karşılaştırma testlerinden Schefee Testi kullanılmıştır. Bunun kullanılmasının sebebi Schefee Testi'nin gerçekten büyük farkl11ıkları anlamlı göstermesidir.

\section{BULGULAR VE YORUM}

$\mathrm{Bu}$ bölümde araştırmanın her bir alt amacına ilişkin bulgular sunulmuştur. Tablo 2'de Fakülte Yaşamının Niteliği Ölçeği alt ölçek puanları ve toplam puanın fakültelere göre karşılaştırılmasına ilişkin tek yönlü varyans analizi sonuçlarına yer verilmiştir.

Tablo 2'de yer alan, ANOVA sonuçları incelendiğinde, "Sınıf Ortamı ve Öğrenci İlişkilerinden Memnuniyet" boyutunda anlamlı fark görülmezken, diğer iki boyut ve toplam puanda farkların anlamlı olduğu görülmektedir. "Öğretim Elemanlarından Memnuniyet" boyutunda, Fen Fakültesi ile Eğitim Bilimleri Fakültesi; Fen Fakültesi ile İlahiyat Fakültesi arasındaki farkların anlamlı olduğu saptanmıştır. Burada bu boyut ile ilgili olarak en yükssek ortalamaya Fen Fakültesi $(\bar{X}=28.95)$ öğrencilerinin, en düşük ortalamaya ise İlahiyat Fakültesi $(\bar{X}=26.80)$ öğrencilerinin sahip olduğu belirlenmiştir. Buna göre Fen Fakültesi öğrencilerinin, araştırma kapsamındaki diğer fakültelerin öğrencilerine göre, öğretim elemanlarından daha memnun oldukları söylenebilir. 
Tablo 2. Fakülte yaşamının niteliği ölçeği alt ölçek puanları ve toplam puanın fakültelere göre karşıllaştırılması

\begin{tabular}{|c|c|c|c|c|c|c|c|c|}
\hline Boyutlar & Fakülte & $\mathbf{N}$ & $X$ & $\mathbf{S}$ & Sd & $\mathbf{F}$ & $\mathbf{p}$ & $\begin{array}{c}\text { Anlamlı } \\
\text { Fark }\end{array}$ \\
\hline \multirow{5}{*}{$\begin{array}{l}\text { 1. Sinıf Ortamı } \\
\text { ve Öğrenci } \\
\text { İlişkilerinden } \\
\text { Memnuniyet }\end{array}$} & A. Ziraat F. & 120 & 12.91 & 2.27 & \multirow[t]{5}{*}{4,68} & \multirow[t]{5}{*}{1.43} & \multirow[t]{5}{*}{0.22} & \multirow[t]{5}{*}{-} \\
\hline & B. Fen F. & 110 & 13.29 & 2.46 & & & & \\
\hline & C. Eğitim B. F. & 245 & 12.91 & 2.05 & & & & \\
\hline & D. İlahiyat F. & 124 & 12.84 & 2.01 & & & & \\
\hline & E. BESYO & 91 & 12.58 & 2.01 & & & & \\
\hline 2. Öğretim & A. Ziraat F. & 120 & 27.68 & 4.53 & 4,68 & 4.12 & 0.00 & B-C \\
\hline Elemanlarından & B. Fen F. & 110 & 28.95 & 5.15 & & & & \multirow[t]{4}{*}{ B-D } \\
\hline \multirow[t]{3}{*}{ Memnuniyet } & C. Eğitim B. F. & 245 & 27.34 & 4.13 & & & & \\
\hline & D. İlahiyat F. & 124 & 26.80 & 3.93 & & & & \\
\hline & E. BESYO & 91 & 27.02 & 4.86 & & & & \\
\hline 3. Fakülteden & A. Ziraat F. & 120 & 25.83 & 3.80 & 4,68 & 8.42 & 0.00 & A-D \\
\hline \multirow[t]{4}{*}{ Memnuniyet } & B. Fen F. & 110 & 25.69 & 4.25 & & & & $\mathrm{E}-\mathrm{C}$ \\
\hline & C. Eğitim B. F. & 245 & 26.30 & 3.61 & & & & \multirow[t]{3}{*}{$\mathrm{C}-\mathrm{D}$} \\
\hline & D. İlahiyat F. & 124 & 24.17 & 3.65 & & & & \\
\hline & E. BESYO & 91 & 24.47 & 3.98 & & & & \\
\hline \multirow[t]{5}{*}{ Toplam } & A. Ziraat $\mathrm{F}$. & 120 & 66.42 & 8.39 & 4,68 & 5.44 & 0.00 & B-D \\
\hline & B. Fen F. & 110 & 67.94 & 10.06 & & & & \multirow[t]{4}{*}{ B-E } \\
\hline & C. Eğitim B. F. & 245 & 66.56 & 7.61 & & & & \\
\hline & D. İlahiyat F. & 124 & 63.81 & 6.74 & & & & \\
\hline & E. BESYO & 91 & 64.08 & 8.30 & & & & \\
\hline
\end{tabular}

"Fakülteden Memnuniyet" boyutunda Ziraat Fakültesi ile İlahiyat Fakültesi, Beden Eğitimi ve Spor Yüksek Okulu ile İlahiyat Fakültesi ve Eğitim Bilimleri Fakültesi ile İlahiyat Fakültesi arasındaki farkların anlamlı olduğu belirlenmiştir. Bu boyut ile ilgili olarak en yüksek ortalamaya Eğitim Bilimleri Fakültesi ( $\bar{X}=26.30$ ) öğrencilerinin, en düşük ortalamaya ise yine İlahiyat Fakültesi $(\bar{X}=24.17)$ öğrencilerinin sahip olduğu belirlenmiştir. Buna göre Eğitim Bilimleri Fakültesi öğrencilerinin, araştırma kapsamındaki diğer fakültelerin öğrencilerine göre, fakültelerinden daha memnun oldukları söylenebilir.

Toplam puanda ise Fen Fakültesi ve Beden Eğitimi ve Spor Yüksek Okulu; Fen Fakültesi ve İlahiyat Fakültesi arasındaki farkların anlamlı olduğu saptanmıştır. Bu boyut ile ilgili olarak en yüksek ortalamaya Fen Fakültesi ( $\bar{X}=67.94)$ öğrencilerinin, en düşük ortalamaya ise yine İlahiyat Fakültesi ( $\bar{X}=63.81)$ öğrencilerinin sahip olduğu belirlenmiştir. Buna göre toplam puanda da Fen Fakültesi öğrencilerinin, araştırma kapsamındaki diğer fakültelerin öğrencilerine göre, genel olarak fakülte yaşamından daha memnun oldukları söylenebilir. 
Yukarıda da görüldüğü gibi fark çıksın ya da çıkmasın İlahiyat Fakültesi öğrencilerinin, genellikle diğer fakültelerde öğrenim gören öğrencilere göre daha olumsuz görüşler içinde oldukları belirlenmiştir. Diğer fakülte öğrencilerine göre, genellikle olumlu görüşler içinde olan fakülte ise Fen Fakültesi'dir. Tablo 3'te Fakülte Yaşamının Niteliği Ölçeği alt ölçek puanları ve toplam puanın cinsiyete göre karşılaştırılmasına ilişkin ilişkisiz t testi sonucu yer almaktadır.

Tablo 3. Fakülte yaşamının niteliği ölçeği alt ölçek puanları ve toplam puanın cinsiyete göre karşılaştırılması

\begin{tabular}{llllllll}
\hline Boyutlar & Cinsiyet & $\mathbf{N}$ & $\bar{X}$ & $\mathbf{S}$ & sd & t & p \\
\hline $\begin{array}{l}\text { 1.Sınıf Ortamı ve Öğrenci } \\
\text { Illiškilerinden }\end{array}$ & Erkek & 326 & 12.65 & 2.26 & 688 & 3.13 & 0.00 \\
Memnuniyet & Kiz & 364 & 13.16 & 2.02 & & & \\
\hline $\begin{array}{l}\text { 2.Öğretim } \\
\text { Elemanlarından }\end{array}$ & Erkek & 326 & 27.44 & 4.80 & 648.08 & 0.43 & 0.67 \\
Memnuniyet & Kiz & 364 & 27.59 & 4.17 & & & \\
\hline 3.Fakülteden Memnuniyet & Erkek & 326 & 24.75 & 3.88 & 688 & 4.81 & 0.00 \\
& Kiz & 364 & 26.16 & 3.77 & & & \\
\hline Toplam & Erkek & 326 & 64.84 & 8.61 & 688 & 3.30 & 0.00 \\
& Kiz & 364 & 66.90 & 7.77 & & & \\
\hline
\end{tabular}

Tablo 3'te yer alan $t$ testi sonuçları incelendiğinde, ikinci boyut olan "Öğretim Elemanlarından Memnuniyet" boyutunda, cinsiyete göre anlamlı bir farklılığın olmadığ 1 görülmektedir $\left[\mathrm{t}_{(648,08)}=0.43 ; \mathrm{p}>0.05\right]$. Buna göre, öğrencilerin öğretim elemanları ile olan etkileşimlerinin ve eğitime dayalı öğrenci değerlendirmelerinin cinsiyete göre değişmediği söylenebilir. Yani öğretim elemanlarının öğrencilere yaklaşımında ya da bir başka deyişle öğrencilerin, öğretim elemanlarının yaklaşımına ilişkin algılarında bir farklılaşma olmadığı görülmektedir. Buna karşılık, "Sınıf Ortamı ve Öğrenci İlişkilerinden Memnuniyet $\left[\mathrm{t}_{(688)}=3.13 ; \mathrm{p}<0.01\right]$ ", "Fakülteden Memnuniyet $\left[\mathrm{t}_{(688)}=4.81 ; \mathrm{p}<0.01\right]$ " ve "Toplam Puana $\left[\mathrm{t}_{(688)}=3.30 ; \mathrm{p}<0.01\right]$ " ilişkin farklı1ıkların anlamlı olduğu belirlenmiştir.

Sınıf Ortamı ve Öğrenci İlişkilerinden Memnuniyet boyutu ile ilgili olarak kız öğrencilerin $(\bar{X}=13.16)$ erkek öğrencilere $(\bar{X}=12.65)$ göre daha olumlu görüsse sahip olduğu görülmektedir. Fakülteden Memnuniyet boyutu ile ilgili olarak da benzer bir durum söz konusudur. Bu boyutta da k1z ögrenciler $(\bar{X}=26.16)$ erkek öğrencilere $(\bar{X}=24.75)$ göre daha olumlu görüş belirtmişlerdir. Fakülte yaşamının niteliği ile ilgili alt boyutlarda olduğu gibi toplam puana ilişkin olarak da k1z öğrencilerin $(\bar{X}=66.90)$ 
erkek öğrencilere göre $(\bar{X}=64.84)$ daha olumlu görüşler içerisinde oldukları belirlenmiştir. Buna göre bu boyutlar ve ölçeğin tamamı ile ilgili olarak kız öğrencilerin daha olumlu görüşlere sahip oldukları söylenebilir. Tablo 4'te Fakülte Yaşamının Niteliği Ölçeği alt ölçek puanları ve toplam puanın yaşlara göre karşılaştırılmasına ilişkin tek yönlü ANOVA sonucu yer almaktadır.

Tablo 4. Fakülte yaşamının niteliği ölçeği alt ölçek puanları ve toplam puanın yaşlara göre karşılaştırılması

\begin{tabular}{|c|c|c|c|c|c|c|c|c|}
\hline Boyutlar & Yaş & $\mathbf{N}$ & $\bar{X}$ & $\mathbf{S}$ & Sd & $\mathbf{F}$ & p & $\begin{array}{c}\text { Anlamlı } \\
\text { Fark }\end{array}$ \\
\hline \multirow{4}{*}{$\begin{array}{l}\text { 1. Sınıf Ortamı } \\
\text { ve Öğrenci } \\
\text { İlişkilerinden } \\
\text { Memnuniyet }\end{array}$} & A. $18-19$ & 97 & 68.39 & 8.29 & \multirow[t]{4}{*}{3,68} & \multirow[t]{4}{*}{6.07} & \multirow[t]{4}{*}{0.00} & \multirow{4}{*}{$\begin{array}{l}\text { A-C, } \\
\text { A-D }\end{array}$} \\
\hline & B. $20-21$ & 313 & 66.23 & 8.18 & & & & \\
\hline & C. $22-23$ & 194 & 65.30 & 7.81 & & & & \\
\hline & $\begin{array}{l}\text { D. } 24 \text { ve } \\
\text { üstü }\end{array}$ & 86 & 63.48 & 8.61 & & & & \\
\hline \multirow{4}{*}{$\begin{array}{l}\text { 2. Öğretim } \\
\text { Elemanlarından } \\
\text { Memnuniyet }\end{array}$} & A. $18-19$ & 97 & 13.25 & 2.13 & \multirow[t]{4}{*}{3,68} & \multirow[t]{4}{*}{1.99} & \multirow[t]{4}{*}{0.11} & \multirow[t]{4}{*}{-} \\
\hline & B. $20-21$ & 313 & 12.97 & 2.11 & & & & \\
\hline & C. $22-23$ & 194 & 12.85 & 2.12 & & & & \\
\hline & $\begin{array}{l}\text { D. } 24 \text { ve } \\
\text { üstü }\end{array}$ & 86 & 12.50 & 2.32 & & & & \\
\hline \multirow{4}{*}{$\begin{array}{l}\text { 3. Fakülteden } \\
\text { Memnuniyet }\end{array}$} & A. $18-19$ & 97 & 28.39 & 4.06 & \multirow[t]{4}{*}{3,68} & \multirow[t]{4}{*}{2.48} & \multirow[t]{4}{*}{0.06} & \multirow[t]{4}{*}{-} \\
\hline & B. $20-21$ & 313 & 27.63 & 4.56 & & & & \\
\hline & C. $22-23$ & 194 & 27.28 & 4.20 & & & & \\
\hline & $\begin{array}{l}\text { D. } 24 \text { ve } \\
\text { üstü }\end{array}$ & 86 & 26.69 & 5.10 & & & & \\
\hline \multirow[t]{4}{*}{ Toplam } & A. $18-19$ & 97 & 26.75 & 4.25 & \multirow[t]{4}{*}{3,68} & \multirow[t]{4}{*}{6.86} & \multirow[t]{4}{*}{0.00} & \multirow{4}{*}{$\begin{array}{l}\text { A-C, } \\
\text { A-D, } \\
B-D\end{array}$} \\
\hline & B. $20-21$ & 313 & 25.63 & 3.82 & & & & \\
\hline & C. $22-23$ & 194 & 25.18 & 3.78 & & & & \\
\hline & $\begin{array}{l}\text { D. } 24 \text { ve } \\
\text { üstü }\end{array}$ & 86 & 24.29 & 3.54 & & & & \\
\hline
\end{tabular}

Tablo 4'te yer alan ANOVA sonuçları incelendiğinde, "Sınıf Ortamı ve Öğrenci İlişkilerinden Memnuniyet" boyutundaki ve toplam puandaki farkların yaşlara göre anlamlı olduğu görülmektedir. "Sınıf Ortamı ve Öğrenci İlişkilerinden Memnuniyet" boyutunda "18-19 yaş" ile "22-23 yaş" grupları arasında ve "18-19 yaş" ile "24 yaş ve üstü" grup arasında; toplam puanda ise "18-19 yaş" ile "22-23 yaş", "18-19 yaş" ile "24 yaş ve üstü” ve ayrıca "20-21 yaş" ile "24 yaş ve üstü" gruplar arasındaki farkların anlamlı olduğu belirlenmiştir. 
Her iki puanda da en yüksek ortalamaya sahip grup "18-19 yaş" grubu iken, en düşük ortalamaya sahip grup "24 yaş ve üstüdür". Yani yaş artıkça, hem "Sınıf Ortamı ve Ögrenci İlişkilerinden Memnuniyet" hem de genel olarak fakülte yaşamından memnuniyet azalmaktadır. Tablo 5'te Fakülte Yaşamının Niteliği Ölçeği alt ölçek puanları ve toplam puanın "Fakültenizde Herhangi Bir Öğrenci Topluluğuna Üye misiniz?" sorusuna verilen yanttlara göre karşılaştırılmasına yönelik ilişkisiz t testi sonucu yer almaktadır. $\mathrm{Bu}$ soru, öğrencilerin herhangi bir öğrenci topluluğuna üye olmalarının, onların fakülteye bağl1lıklarını arttıracağı, bulundukları ortamdan memnuniyetlerini olumlu yönde etkileyeceği öngörüsüyle sorulmuştur.

Tablo 5. Fakülte yaşamının niteliği ölçeği alt ölçek puanları ve toplam puanın öğrenci topluluklarına üyelik durumuna göre karşılaştırılması

\begin{tabular}{llllllll}
\hline \multicolumn{1}{c}{ Boyutlar } & $\begin{array}{l}\text { Topluluk } \\
\text { Üyeliği }\end{array}$ & $\mathbf{N}$ & $\bar{X}$ & $\mathbf{S}$ & sd & t & p \\
& Evet & 162 & 12.73 & 1.99 & 320.66 & 1.23 & 0.22 \\
\hline 1.Sinıf Ortamı ve & Hayır & 528 & 12.97 & 2.19 & & & \\
$\begin{array}{l}\text { Öğrenci İlişkilerinden } \\
\text { Memnuniyet }\end{array}$ & Evet & 162 & 26.65 & 3.88 & 688 & 3.12 & 0.00 \\
\hline 2.Öğretim & Hayır & 528 & 27.79 & 4.62 & & & \\
Elemanlarından & & & & & & & 0.64 \\
Memnuniyet & Evet & 162 & 25.37 & 3.48 & 313.65 & 0.47 & 0.04 \\
\hline 3.Fakülteden & Hayır & 528 & 25.53 & 4.01 & & & \\
Memnuniyet & Evet & 162 & 64.75 & 7.02 & 688 & 2.31 & 0.02 \\
\hline Toplam & Hayır & 528 & 66.29 & 8.55 & & & \\
\hline
\end{tabular}

Tablo 5'te yer alan $\mathrm{t}$ testi sonuçları incelendiğinde, ikinci boyut olan "Öğretim Elemanlarından Memnuniyet" boyutunda $\left[\mathrm{t}_{(688)}=3.12 ; \mathrm{p}<0.01\right]$ ve toplam puanda $\left[\mathrm{t}_{(688)}=2.31 ; \mathrm{p}<0.05\right]$ anlamlı farklılıkların olduğu görülürken, diğer boyutlarda anlamlı fark görülmemektedir. Tablo 6'da Fakülte Yaşamının Niteliği Ölçeği alt ölçek puanları ve toplam puanın "Ders Dışı Zamanlarınızı Fakültede Geçirmeyi Tercih Ediyor Musunuz?" sorusuna verilen yanıtlara göre karşılaştırılmasına yönelik ilişkisiz t testi sonucu yer almaktadır.

Tablo 6'da yer alan $t$ testi sonuçları incelendiğinde, hiçbir alt boyutta ve toplam puanda gruplar arasındaki farkların anlamlı olmadığı görülmektedir. Tablo 7'de Fakülte Yaşamının Niteliği Ölçeği alt ölçek puanları ve toplam puanın sınıf düzeylerine göre karşılaştırılmasına ilişkin ANOVA sonucu yer almaktadır. 
Tablo 6. Fakülte yaşamının niteliği ölçeği alt ölçek puanları ve toplam puanın ders dışı zamanları fakültede geçirmeyi tercih etme durumuna göre karşılaştırılması

\begin{tabular}{|c|c|c|c|c|c|c|c|}
\hline Boyutlar & $\begin{array}{l}\text { Fakülttede } \\
\text { Zaman } \\
\text { Geçirme }\end{array}$ & $\mathbf{N}$ & $\bar{X}$ & $\mathbf{S}$ & sd & $\mathbf{t}$ & $\mathbf{p}$ \\
\hline 1.Sınıf Ortamı ve & Evet & 236 & 13.02 & 2.20 & 688 & 0.97 & 0.34 \\
\hline $\begin{array}{l}\text { Öğrenci İlişkilerinden } \\
\text { Memnuniyet }\end{array}$ & Hayır & 454 & 12.86 & 2.12 & & & \\
\hline 2.Öğretim & Evet & 236 & 27.41 & 4.45 & 688 & 0.46 & 0.65 \\
\hline $\begin{array}{l}\text { Elemanlarından } \\
\text { Memnuniyet }\end{array}$ & Hayır & 454 & 27.57 & 4.50 & & & \\
\hline 3.Fakülteden & Evet & 236 & 25.57 & 4.17 & 432.82 & 0.37 & 0.71 \\
\hline Memnuniyet & Hayır & 454 & 25.46 & 3.74 & & & \\
\hline \multirow[t]{2}{*}{ Toplam } & Evet & 236 & 66.01 & 8.23 & 688 & 0.18 & 0.86 \\
\hline & Hayır & 454 & 65.89 & 8.25 & & & \\
\hline
\end{tabular}

Tablo 7. Fakülte yaşamının niteliği ölçeği alt ölçek puanları ve toplam puanın sınıf düzeylerine göre karșlaștırılması

\begin{tabular}{lcccccccc}
\hline \multicolumn{1}{c}{ Boyutlar } & Sınıf & $\mathbf{N}$ & $\bar{X}$ & $\mathbf{S}$ & $\mathbf{s d}$ & $\mathbf{F}$ & $\mathbf{p}$ & $\begin{array}{c}\text { Anlamlı } \\
\text { Fark }\end{array}$ \\
\hline 1. Sınıf Ortamı ve & 2. sinıf & 210 & 12.97 & 2.14 & 2, & 1.15 & 0.32 & - \\
Öğrenci & 3.sınıf & 335 & 12.99 & 2.21 & 68 & & & \\
İlişkilerinden & $4 . \operatorname{sinıf}$ & 145 & 12.68 & 1.99 & & & & \\
Memnuniyet & & & & & & & & $2-4$ \\
\hline 2. Öğretim & 2. sinıf & 210 & 28.13 & 4.39 & 2, & 4.83 & 0.00 & \\
Elemanlarından & 3.sınıf & 335 & 27.52 & 4.52 & 68 & & & \\
Memnuniyet & 4.sinıf & 145 & 26.63 & 4.38 & & & & \\
\hline 3. Fakülteden & 2. sinıf & 210 & 26.02 & 4.05 & 2, & 3.09 & 0.04 & $2-4$ \\
Memnuniyet & 3.sinıf & 335 & 25.35 & 3.71 & 68 & & & \\
& 4.sinıf & 145 & 25.06 & 3.99 & & & & \\
\hline Toplam & 2. sinıf & 210 & 67.12 & 8.65 & 2, & 4.85 & 0.00 & $2-4$ \\
& 3.sinıf & 335 & 65.86 & 8.11 & 68 & & & \\
\hline & 4.sinıf & 145 & 64.37 & 7.67 & & & & \\
\hline
\end{tabular}

Tablo 7'de yer alan ANOVA sonuçları incelendiğinde, "Sınıf Ortamı ve Öğrenci İlişkilerinden Memnuniyet" boyutu hariç, diğer iki boyut ve toplam puanda, ikinci ve dördüncü sınıflar arasındaki farkların anlamlı olduğu, tüm puanlarda ikinci sınıfların ortalamalarının daha yüksek olduğu görülmektedir. Yani alt sinıflarda öğrencilerin genel olarak fakülte yaşamından memnuniyetleri daha yüksekken, sınıf düzeyi yükseldikçe bu memnuniyetin azaldığı görülmektedir. Benzer bulgu daha önce yaş değişkeni için de elde edilmiştir. Yaş artıkça fakülte yaşamından memnuniyet azalmaktadır. Tablo 4'te yer alan bulgularda da görüldüğü gibi, hem toplam puanda hem de alt boyutlarda, yaş grupları içinde en düşük ortalama "24 ve 
üstü" yaş grubuna, en yüksek ortalama ise "18-19" yaş grubuna aittir. Bu durum iki değişken ile ilgili olarak elde edilen bulgular arasında tutarlılık olduğunu göstermektedir. Tablo 8'de Fakülte Yaşamının Niteliği Ölçeği alt ölçek puanları ve toplam puanın öğrenim gördükleri bölümleri tercih etme sıralarına göre karşılaştırılmasına ilişkin ANOVA sonucu yer almaktadır.

Tablo 8. Fakülte yaşamının niteliği ölçeği alt ölçek puanları ve toplam puanın fakülteyi tercih etme sırasına göre karşılaştırılması

\begin{tabular}{llccccccc}
\hline Boyutlar & $\begin{array}{l}\text { Tercih } \\
\text { Sırası }\end{array}$ & $\mathbf{N}$ & $\bar{X}$ & $\mathbf{S}$ & sd & $\mathbf{F}$ & $\mathbf{p}$ & $\begin{array}{c}\text { Anlaml } \\
\text { Fark }\end{array}$ \\
\hline 1.Sinıf Ortamı & A.1-5 & 460 & 12.88 & 2.13 & 2,687 & 0.19 & 0.82 & - \\
ve Öğrenci & B.6-10 & 130 & 13.00 & 2.14 & & & & \\
İlişkilerinden & C.11 ve + & 100 & 12.97 & 2.26 & & & & \\
Memnuniyet & & & & & & & & \\
\hline 2.Öğretim & A.1-5 & 460 & 27.21 & 4.43 & 2,687 & 3.42 & 0.03 & A-B \\
Elemanlarından & B.6-10 & 130 & 28.25 & 4.57 & & & & \\
Memnuniyet & C.11 ve + & 100 & 28.00 & 4.48 & & & & \\
\hline 3.Fakülteden & A.1-5 & 460 & 24.90 & 3.66 & 2,687 & 17.97 & 0.00 & A-B, \\
Memnuniyet & B.6-10 & 130 & 26.97 & 3.87 & & & & AC \\
& C.11 ve + & 100 & 26.33 & 4.28 & & & & \\
\hline Toplam & A.1-5 & 460 & 64.99 & 7.81 & 2,687 & 9.64 & 0.00 & A-A, \\
& B.6-10 & 130 & 68.22 & 8.37 & & & & A-C \\
& C.11 ve + & 100 & 67.30 & 9.21 & & & & \\
\hline
\end{tabular}

Tablo 8'de yer alan, Fakülte Yaşamının Niteliği Ölçeği alt ölçek puanları ve toplam puanın öğrenim görülen bölümü tercih etme sırasına göre karşılaştırılmasına ilişkin ANOVA sonuçları incelendiğinde "Sınıf Ortamı ve Öğrenci İlişkilerinden Memnuniyet" boyutu hariç, diğer iki boyut ve toplam puanda anlamlı farklar olduğu görülmektedir. "Öğretim Elemanlarından Memnuniyet" boyutunda fakültelerini 1-5. sirada tercih edenler ile 610.sirada tercih edenler arasinda anlamlı fark bulunmaktadır. Gruplara ait ortalamalar incelendiğinde, 6-10.sirada tercih edenlerin ortalamalarının daha yüksek olduğu görülmektedir. "Fakülteden Memnuniyet" alt boyutunda 1-5. sirada tercih edenler ile 6-10.sirada tercih edenler; $1-5$. sirada tercih edenler ile 11 ve üzeri sırada tercih edenler arasındaki farklar anlamlıdır. Grupların ortalamaları incelendiğinde, en yüksek ortalama 6-10. sirada tercih edenlere ait iken, en düşük ortalama 1-5. sırada tercih edenlere aittir. Toplam puanda da yine 1-5. sirada tercih edenler ile 6-10.sirada tercih edenler; $1-5$. sirada tercih edenler ile 11 ve üzeri sırada tercih edenler arasındaki farklar anlamlıdır. Yine en yüksek ortalama 6-10. sırada tercih edenlere ait iken, en düşük ortalama $1-5$. sirada tercih edenlere aittir. 
Tablo 9'da Fakülte Yaşamının Niteliği Ölçeği alt ölçek puanları ve toplam puanın "tekrar tercih etme şansınız olsa, aynı fakülteyi tercih eder miydiniz?" sorusuna göre karşılaştırılmasına yönelik ilişkisiz t testi sonuçları yer almaktadır.

Tablo 9. Fakülte yaşamının niteliği ölçeği alt ölçek puanları ve toplam puanın fakülteyi tekrar tercih etme isteklerine göre karşılaştırılması

\begin{tabular}{llllllll}
\hline \multicolumn{1}{c}{ Boyutlar } & $\begin{array}{l}\text { Tekrar } \\
\text { Tercih }\end{array}$ & $\mathbf{N}$ & $\bar{X}$ & $\mathbf{S}$ & sd & t & p \\
\hline 1.Sinıf Ortamı ve Öğrenci & Evet & 428 & 12.85 & 2.15 & 688 & 0.99 & 0.32 \\
Illişkilerinden Memnuniyet & Hayır & 262 & 13.02 & 2.15 & & & \\
\hline 2.Öğretim Elemanlarından & Evet & 428 & 27.37 & 4.54 & 688 & 1.14 & 0.26 \\
Memnuniyet & Hayır & 262 & 27.77 & 4.37 & & & \\
\hline 3.Fakülteden Memnuniyet & Evet & 428 & 25.30 & 3.69 & 499.77 & 1.67 & 0.10 \\
& Hayır & 262 & 25.82 & 4.18 & & & \\
\hline Toplam & Evet & 428 & 65.52 & 8.14 & 688 & 1.69 & 0.09 \\
& Hayır & 262 & 66.61 & 8.36 & & & \\
\hline
\end{tabular}

$\mathrm{Bu}$ soru, öğrencilerin fakültelerine isteyerek tercih edip etmemelerinin, onların fakültelerini değerlendirmeye yönelik algılarında etkili olacağ öngörüsünden yola çıkılarak sorulmuştur. Ancak, Tablo 9'da yer alan, Fakülte Yaşamının Niteliği Ölçeği alt ölçek puanları ve toplam puanın "tekrar tercih etme şansınız olsa aynı fakülteyi tercih eder miydiniz?" sorusuna verilen yanitlara göre karşılaştırılmasına ilişkin $t$ testi sonuçları incelendiğinde, hiçbir alt boyutta ve toplam puanda, gruplar arasındaki farkların anlamlı olmadığı saptanmıştır.

\section{SONUÇ VE ÖNERILER}

\section{Sonuç}

Fakülteler, üniversite öğrencilerinin yaşantılarının önemli bölümünü geçirdikleri, ergenlikten yetişkinlik rollerine geçiş sürecinin önemli bir kısmını kapsayan ve bu anlamda da sonraki yaşamda başarılı bireyler olup olmamalarının temellerinin büyük bir bölümünün atıldığı kurumlardır. Yani fakülteler sadece öğretim kurumu olmanın çok daha ötesinde işleve sahiptir ve bu anlamda da pek çok farklı yaşantı ve gelişimlere sahne olmaktadır. Bu nedenle de fakültelerdeki yaşamın niteliğinin araştırılması, öğrencilerin hem akademik hem de kişisel gelişimleri açısından son derece önemli görülmektedir.

$\mathrm{Bu}$ çalışmada, Çokluk-Bökeoğlu ve Yılmaz (2006) tarafından geliştirilmiş olan "Fakülte Yaşamının Niteliği Ölçeği” kullanılarak ögrencilerin fakültelerine ilişkin alg1 ve değerlendirmeleri, yine fakülte 
yaşamının niteliğini etkileyebileceği düşünülen bazı değişkenler açısından karşılaştırılarak incelenmiştir.

Öğrencilerin Fakülte Yaşamının Niteliği Ölçeği'ne verdikleri yanıtların fakültelere göre karşılaştırılmasına ilişkin sonuçlar incelendiğinde, "Sınıf Ortamı ve Öğrenci İlişkilerinden Memnuniyet" boyutunda fakülteler arasında anlamlı fark görülmezken, diğer iki boyut olan "Öğretim Elemanlarından Memnuniyet" ve "Fakülteden Memnuniyet" boyutunda ve ayrıca toplam puanda farkların anlamlı olduğu görülmektedir. "Öğretim Elemanlarından Memnuniyet" boyutunda en yüksek ortalamaya Fen Fakültesi, en düşük ortalamaya ise İlahiyat Fakültesi öğrencileri sahiptir. "Fakülteden Memnuniyet" boyutunda en yüksek ortalama Eğitim Bilimleri Fakültesi öğrencilerine aitken, en düşük ortalama İlahiyat Fakültesi öğrencilerine aittir. Toplam puanda da benzer bir durum gözlenmekte, Fen Fakültesi öğrencilerinin ortalamalarının en yüksek, İlahiyat Fakültesi öğrencilerinin ortalamalarının en düşük olduğu görülmektedir. Bu durumda genel olarak Fen Fakültesi öğrencilerinin fakültelerine ilişkin alg1 ve değerlendirmelerinin daha olumlu olduğu, İlahiyat Fakültesi öğrencilerinin ise görece daha olumsuz olduğu söylenebilir.

Cinsiyete ilişkin karşılaştırmalarda kızların ortalamasının erkeklerden yüksek olması, kızların ve erkeklerin mevcut koşulları aynı şekilde değerlendirmedikleri anlamına gelmekte ve kızların alg1 ve değerlendirmelerinin, erkeklere göre daha olumlu olduğunu göstermektedir. Aslında bu farklılık, öğrencilerin koşulları değerlendirmede kullandıkları ölçüt ve beklentilerin farklılığından kaynaklanıyor olabilir. Her türlü ideal koşulun sağlandığı durumlarda bile bireylerin bundan memnuniyetlerinin, beklentilerinin gerçekçilik düzeyi ile sınırlı olduğu söylenebilir.

Öğrencilerin yaşlarına göre yapılan karşılaştırmalar incelendiğinde "Sınıf Ortamı ve Öğrenci İlişkilerinden Memnuniyet" boyutunda ve toplam puandaki farkların anlamlı olduğu görülmektedir. Genel olarak daha genç yaştaki öğrencilerin ortalamalarının daha yüksek olduğu saptanmıştır. Ayrıca yine sınıf düzeyine göre yapılan karşılaştırmalarda da alt sınıflardaki öğrencilerin genel olarak fakülte yaşamının niteliğine ilişkin değerlendirmeleri daha olumlu iken, sınıf düzeyi yükseldikçe bu memnuniyetin azaldığı görülmektedir. Bu durum, sınıf düzeyi ilerledikçe ve bununla bağlantılı olarak yaş arttıkça, öğrencilerin farklı ortamlarının oluşmasından, çevreyi tanıma ve uyum sağlama ile birlikte ilgilerinin fakülte dışında başka ortamlara yönelmesinden kaynaklanıyor olabilir. Bir diğer neden de fakültede artık alıştıkları bir takım özellikleri ya da nitelikleri daha sıradan ya da olağan bulmaları olabilir. 
Fakülte Yaşamının Niteliği Ölçeği alt ölçek puanları ve toplam puanın "fakültenizde herhangi bir öğrenci topluluğuna üye misiniz?" sorusuna verilen yanıtlara göre karşılaştırılmasına ilişkin sonuçlar incelendiğinde anlamlı fark olsun ya da olmasın tüm boyutlarda ve toplam puanda herhangi bir öğrenci topluluğuna üye olmayanların puanlarının daha yüksek olması, aslında beklenenin aksine bir bulgudur. Bu belki de fakültelerinden fazla memnun olmayan öğrencilerin, bu memnuniyetsizliklerini bir miktar azaltmak adına başka etkinliklere yönelmeyi tercih ettikleri şeklinde yorumlanabilir.

"Ders dışı zamanlarınızı fakültede geçirmeyi tercih ediyor musunuz?" sorusuna verilen yanıtlara göre yapılan karşılaştırmada, hiçbir alt boyutta ve toplam puanda "evet" ya da "hayır" yanıtını verenler arasındaki farkların anlamlı olmadığı görülmektedir. Yine fakültede zaman geçirmeyi tercih edip etmemek, fakülte yaşamının niteliğine ilişkin algı ve değerlendirmeleri etkileyen önemli bir değişken olarak görülmemektedir.

Öğrencilerin öğrenim gördükleri bölümü tercih sıralarına yapılan karşılaştırmada, genel olarak en yüksek ortalama 6-10. sirada tercih edenlere ait iken, en düşük ortalamanın 1-5. sirada tercih edenlere ait olduğu görülmektedir. $\mathrm{Bu}$ bulgu, fakültelerini $1-5$. sirada tercih edenlerin beklentilerinin daha yüksek olduğu, hatta belki de çok gerçekçi düzeyde olmadığı, bu nedenle de algı ve değerlendirmelerinin daha olumsuz olduğu şeklinde yorumlanabilir. "Tekrar tercih etme şansınız olsa aynı fakülteyi tercih eder miydiniz?" sorusuna verilen yanitlara göre yapılan karşılaştırılmalar incelendiğinde ise, yine hiçbir alt boyutta ve toplam puanda, bu soruya "evet" ya da "hayır" yanıtını verenler arasındaki farkların anlamlı olmadığı saptanmıştır. Öğrencilerin fakültelerini tekrar tercih edip etmemelerini etkileyen faktörler, fakülte yaşamının incelenmeyen diğer başka boyutlarına ilişkin olabileceği gibi, diğer bazı kişisel, çevresel ya da sosyal değişkenlerle ilişkili olabilir.

\section{Öneriler}

Fakülte yaşamının niteliğinin fakültedeki derslikler, kütüphane, kantin/kafeterya, spor salonu, bilgisayar laboratuarı, yemekhane vb. fiziki mekânların yeterliği, fakültede düzenlenen sosyo-kültürel etkinlikler, fakültede çalışan idari personel ile ilişkiler, düzenlenen bilimsel etkinlikler gibi başka bazı değişkenler açısından incelenmesinin önemli olacağı düşünülmektedir. Yine öğrencilerin fakülte yaşamının niteliğine ilişkin algı ve değerlendirmelerinin akademik başarıları ve bir takım psikolojik özellikleri ile ilișkilendirilerek incelenmesi yararlı olabilir. Genel olarak fakülte yaşamının niteliğine ilişkin çalışmaların, tüm fakültelerde yapılması 
ve elde edilen verilerin bir geri dönüt olarak kullanılması, fakültelerin gelişimi açısından katkı sağlayacak niteliktedir. Yaşadığımız çağda eğitim kurumlarının niteliğini artırmaya yönelik arayışlarda, bu kurumların ve hatta sistemin varlık nedenini oluşturan öğrencilerin görüşlerinin dikkate alınması ve seslerine kulak verilmesinin, paha biçilemez katkılar getireceği yadsinamaz.

$\mathrm{Bu}$ araştırmada üniversite öğrencilerinin fakülte yaşamının niteliği ile ilgili görüşleri ve bu görüşlerin fakülte, cinsiyet, yaş, sınıf, fakültede herhangi bir öğrenci topluluğuna üye olma, ders dışı zamanları fakültede geçirme, öğrenim görülen bölümü tercih sırası, tekrar tercih etme şans1 olsaydı, aynı fakülteyi tercih etmeyi isteyip istememe değişkenlerine göre değişip değişmediği belirlenmeye çalışılmıştır. Bundan sonraki araştırmalarda fakülteler arasında fen, sosyal, sağlık ayrımına göre, fakültelerde düzenlenen etkinliklerin sayısına ve durumuna göre, öğretim elemanları ile olan ilişkilerin durumuna göre çalışmalar yapılabilir. 


\section{KAYNAKLAR}

Ainley, J. (1999). "Schools and the social development of young australians: Frameworks, outcomes and influences". Paper presented at the National Social Outcomes of Schooling Forum. Surfers Paradise, Australia.

Bourke, S. ve Smith, M. (1989). Quality of school life and intentions for further education: The case of a rural high school. Paper presented at the Annual Conference of the Australian Association for Research in Education. Adelaide, South Australia. November-December.

Çokluk-Bökeoğlu, Ö ve Yılmaz, K. (2006). Fakülte Yaşamının Niteliği Ölçeği Geçerlik ve Güvenirlik Çalışması. Gazi Üniversitesi Türk Eğitim Bilimleri Dergisi, 4 (2), 201-210.

Epstein, J. L. \& McPartland, J. M. (1976). The concept and measurement of the quality of school life. American Educational Research Journal, 13 (1), 15-30.

Karasar, N. (1995). Bilimsel Araştırma Yöntemi. Ankara: 3A Araştırma Eğitim Danışmanlık Ltd.

Karatzias A., Power K. G. ve Swanson V. (2001). Quality of school life: development and preliminary standardization of an instrument based on performance indicators in scottish secondary schools. School Effectiveness and School Improvement, 12 (3), 265-284.

Kourelahti, M. (1998). Quality of school life in finnish special educational settings (EBD). In A. Antilla \& A. Ulusitalo (Eds.), Contemporary marginalization and exclusion of young people-whose reality counts? (pp. 47-50). Advisory Council for Youth Affairs and Mannerheim League for Child Welfare. Helsinki: Nykypaino.

Leonard, C. A. R. (2002). Quality of life and attendance in primary schools. Yayınlanmamış Doktora Tezi. Newcastle: University of Newcastle. http://www.newcastle.edu.au/services/library/adt/public/adt. Retrieved on 12.12.2005, at URL: NNCU20030702.214022/index.html.

Leonard, C. A. R., Bourke, S. ve Schofield, N. J. (2003a). Student quality of school life - a multilevel analysis. Paper presented at the Annual Conference of the Australian Association for Research in Education. Brisbane, December. Retrieved on 12.12.2005, at URL: $\mathrm{http} / / \mathrm{www}$. aare.edu.au/conf02.htm/leo02.063..

Leonard, C. A. R., Bourke, S. ve Schofield, N. J. (2003b). Affective outcomes in the context of school reform. Paper presented at the NZARE / AARE Joint Conference. Hyatt Regency Hotel \& University of Auckland. 
Leonard, C. A. R., Bourke, S., ve Schofield, N. J. (2001). The effect of stress management and relaxation techniques on student quality of school life and absenteeism in primary schools. Paper presented at the Biennial Conference of the European Association for Research on Learning and Instruction. Fribourg, August.

Leonard, C. A. R., Bourke, S., ve Schofield, N. J. (2002). Student quality of school life differences within and between primary schools. Paper presented at the Annual Conference of the Australian Association for Research in Education, Perth, December. Retrieved on 12.12.2005, at URL: http//www.aare.edu.au/conf01.htm/leo01.130..

Mok, M. ve Flynn, M. (1997). Quality of school life and students' achievement in the hsc: a multilevel analysis. Australian Journal of Education, 41 (2), 169-188.

Mok, M. ve Flynn, M. (2002). Determinants of students' quality of school life: a path model. Learning Environments Research, 5, 275-300.

Mok, M. ve McDonald, M. (1994). Quality of school life: a scale to measure student experience or school climate?. Educational and Psychological Measurement, 54 (2), 483-495.

Schmidt, L. J. (1992). Relationship between pupil control ideology and quality of school life. Journal of Invitational and Psychological Measurement. 45, 889-896.

Schmidt, L. J. ve Lunenburg, F. C. (1989). Pupil control ideology, pupil control behavior and the quality of school life. Journal of Research and Development in Education, 22, 36-44.

Schofield, N. J. ve Bourke, S. F. (1997). Absenteeism, student quality of school life and teacher stress in primary school. Paper presented at the EARLI Conference. Athens.

Şişman, M. ve Turan, S. (2001). Eğitimde Toplam Kalite Yönetimi. Ankara: Pegem A Yayıncilık.

Waugh, R. ve Hyde, N. (1993). Student perceptions of school. Paper presented at the Annual Conference of the Australian Association for Research in Education. Fremantle, November. Retrieved on 12.12.2005, at URL: http//www.swin.edu.au/aare/conf93.htm/waugr 93.239.

Wilson, A. (1980). Landmarks in the literature: how powerful is schooling. New York University Education Quarterly. 11, 8-31.

www.cnu.edu. "Christopher Newport University web sitesi". İndirme Tarihi: 22.12.2005. 